\title{
Contributions to the Variations Among Birds.
}

\author{
By
}

\section{Masauji Hachisuka.}

The present work is an addition to my Supplementary Publication No. XII of "Tori" 1928, on Variations Among Birds.

\section{Heterochrosis.}

The rarest of all colour phases, if classified, may be the "Blue " or "Lavender."

The normal plumage of the Kamchatkan Goshawk (Accipiter gentilis albidus) is white, finely vermiculated with faint blue. It is true that birds in snowy countries have white plumage but it is rare that any remaining colour pattern should be in blue, the Snowy Owl, Greenland and Iceland Falcons all having brown patterns in varying degree.

In the case of the Blue Goose (Anser caerulescens), this may be a species or race to the Snow Goose (A. hyperboreus). Vide Stresemann, J. f. O. 1926.

A field note appeared with photographs, beliovod to be the first published in "American Game," p. 31, March, 1929. The case of interest to the student of variation, mutation, etc.

A study of racial and individual variations among Red-tail Hawks (Buteo borealis) by Mr. P. A. Taverner (Cf. $\Lambda$ study of Buteo borealis, the Red-tailed Hawk and its variations in Canada. Victoria Museum Bulletin No. 48, Biological Series No. 13 , Nov. 11,1927 ) offers us somo interesting points. $\mathrm{Mr}$. 
Momiyama has a specimen of Japanese Crested Ibis (Nipponia nippon) with smoky lue, which was obtained in Gensan, N. Kankyo Dist., Korea in March 1929. It is no doubt a variety denominated Ibis Nippon var. Sinensis a slightly paler specimen than the colourod plate reproduced by David and Oustalet in Les Oiseaux de la Chine, Pl. 117. It gives a habitat of the bird on page 455 .

Mr. A. L. Butler exhibited a melanistic Humming-bird at the B. O. C. dinner (Bulletin Vol. XLVIII, 1927, p. 8). This must be an extremely rare occurrence.

A White Cardinal was recorded (Cf. L Oiseau Vol. X. No. 4,1929 , p. 246 also No. 6,1929 , p. 380) not exactly the first record. Why has this now domesticated finch not established its white variety as in the case of Peafowl, Java Sparrows, Bengalees, etc.?

This Cardinal has a white body with the normal red crest.

The case is parallel to the white Grey Parrot in the British Museum, in which the grey feathers have turned into white, making it appear to be a white bird with red under tail-covert.

An albino Kestrel (Falco naumanni) was recorded in Bull. B. O. C. P. 41-2, Nov. 1928. The first record of its kind I know of.

Prof. Lönnberg writes that the Riksmuseet acquired some more varieties of Tetraonidix and his letter giving a description of some specimens appears to me of much interest.

Mr. Ezra wrote to me on Feb. 1st, 1929 that his unique blue variety of Alexandrine Parrakeet is in good healthy condition. (Variation, Hachisuka, 1928, pl. 11). The lutino Alexandrino hen mated last year to a normal green cock was successful in rearing two young ones but they were green, as is usual. 
(Variation, Hachisuka 1928 p. 19.)

Herr. Neunzig has published a paper on the variations among Weaver Birds, result of his study of the birds in captivity and skins. In Beitrage zur Kenntnins der Ploceiden.

III. Phaenotypische Farbaberrationen, I.

IV. Rassenkreisstudien, I-III.

Zool. Anz., IXX, 1927, pp. 39-44 and 184-199, he deals with melanistic and other variations, which be regards as often due to pathological conditions and which can be frequently brought about by special feeding.

In the same magazine he writes in pp. 235-242 about " mutationen" that there can be little doubt that Estrilda xanthophrys is merely a colour-phase or mutant of $E$. troglodytes.

MeGregor records partially albinistic Capella megala, the phenomenon is uncommonly found among C. gallinago.

Philippine Journ. Se. 13, p. 9, 1918, Pl. III, fig. 3.

\section{Gynandromorphs.}

A perfectly good adult male California Linnet (Carpodacus mexicanus frontalis) determined by Mr. F. N. Bassett on dessection and thought by him to be a breeding bird with enlarged testes on the ground partly that the bird was in song, when collected at Nashmead, Mendoeino County, California on May 7,1926 , exhibits externally plumage indistinguishable from that of a female. Such anthentic evidence is scarce. (Cf. Condor No. 3, 1929, p. 131.)

I understand that, in some biological circles the term "Hermaphroditism " is employed with an enlarged meaning, rather losing its literal sense. It is used to cover any abnormal sexuality including intersexuality (sex reversal) and any exter- 
nal appearance of an adult animal which combines secondary charactors of both sexes in any proportion. When a male of a certain species does not assume its full plumage at the proper time of the year and retaine partially a juvenile garment which does not differ from that of the fully grown female, it is also called by some biologists a hermaphrodite, but this is an error. When an individual possess, though possibly incomplete, both male and female reproductive organs in one body, and bilateral distribution of the two sexual charactors as is often the case with birds and insects, I emumerated a dozen cases in birds (Variations, Hachisuka, p. 26), this is a hermaphrodite in the proper sense of the word. Those who employ the term in too broad a meaning distinguish the above as "true hermaphrodite". Such articles as:

Effect of injection of lipoid fraction of bull testicle in capons, by L. C. McGee (Proc. Inst. Med. 6; 242-244, 1927). Inhibition of male plumage in ovariectomized hen; probable origin of ovarian chalone, by J. Benoil (Compt. rend. Soc. de Biol. 97, 793-796, Aug. 26, 1927). Intersexuality, autonomous sexual inversion in a duck, by Caridroit and Pegard (Compt. rend. Soc. de Biol. 95, 1295-1298, May 30, 1927) are all indexcd in a biological catalogue under the chapter "hermaphrodites." No ornjthologist can follow this view.

\section{Atavism.}

I have seen at least three specimens of a male teal which have white feathers at the neck. This varies to a certain extent in individual. The photograph reproduced here is of one in my collection, which has a complete ring like that of a male mallard.

Fig. 42 represents a common Japanese Jay $(G . g$. 
japonicus) in Momiyama Collection. Its bead, part of the face and the major part of the under part of the body are whitish; normal colouring and patterns are obliterated, the tail feathers being beautifully barred like the wing. At a glance it looks partially albinistic while the disappearance of a certain colour pigment from the tail, removes it so far from nature as to make it identical with the wing. "Barred tail" is uncommon among Jay like birds and Mr. Momiyama pointed out the affinity to Laletris of the Old World and Cyanocitla cristata in the New World.

Cf. Dobutsu. Zasshi (Tokyo Zool. Mag.), Vol. 41, No. 490-491, 1929.

Article No. XVJII., Moniyama writes here on the jay referred to and affinities of Janthoenas $j$. nitens which $I$ have already quoted in my Variation Among Birds on p. 43.

Pycraft reproduced in the Illustrated London News (Feb. 23,1929 ) a figure of an isabelline Rook, drawn by Frowhawk.

This specimen shows complex patterning which is to be an interpretation of an ancestral appearance, now masked by the intensification of the melanin pigment. Intensification of colours among the common Jay tribe is seen in Lidth's Jay, Lalocitta, of Riukiu Is. Its head, wings, and tail are practically uniform dark blue; this bird is confined to the thick and dark forest region of the islands.

A dark blue shade in birds is a common character among the inhabitants of primeral forest in tropical Pacific islands. These forests are very dark and humid and quite different from the open airy places where palms predominate. The nearest ally in this respect to Lalocitta is the Mikado Pheasant, Calophasis mikado of Formosa.

Its continental allies in central Asia are much lighter birds in both sexes. A blue Urocissa in Formosa is also a 


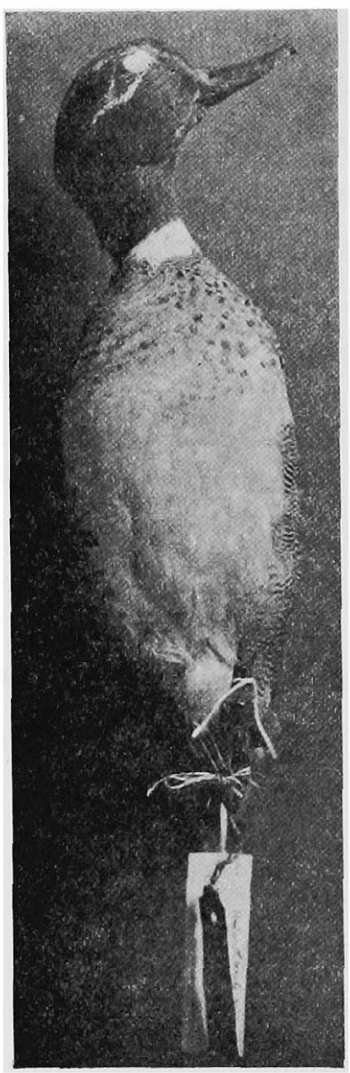

Fig. 41. A male Teal showing a complete ring on neck.

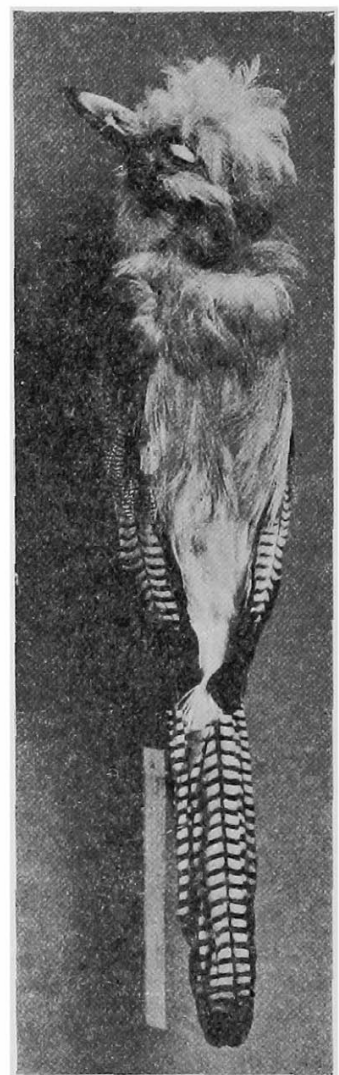

Fig. 42. A Japanese Jay with banded tail-feathers.

mountain bird.

Mr. Joseph Mailliard records (Condor, p. 37, Vol. XXXI, No. 1, 1929) an adult Golden-crowned Sparrow without the yellow feathers on the head captured in Marin County, California, an interesting fact!

\section{Hybrids.}

More valuable than any other paper published since the appearance of my book "Variation" in November last year is no 
doubt Lord Rothschild's in the Bull. B. O. C., No. cecxxxiij when in March he exhibited 103 skins of hybrid Ducks of 49 distinct crosses and two reverse crosses.

Lord Rothschild pointed out that "the most interesting specimen is the hybrid is Carolina $\times$ Wigeon, reared by the late J. H. Bonhote at Ditton Hall, for it shows by the extraordinary elongated tail that all the Anatidae have, lying dormant, the power of producing a tail with extremely lengthened rectrices, though only the four species of Pintail (Dafila acuta) and the Long-tailed Duck (Clangula hyemalis) have actually developed these elongated tails".

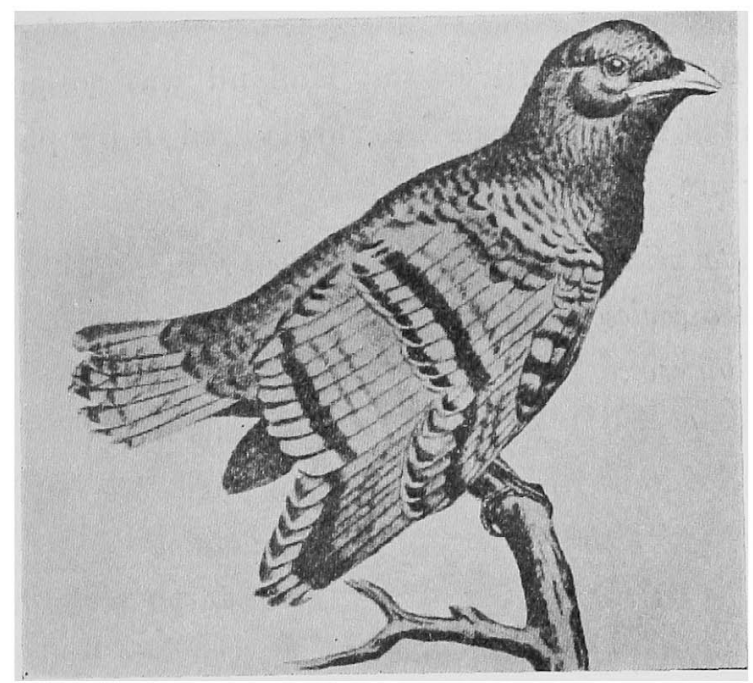

Fig. 43. An isabelline Rook with an ancestral appearance.

(From the Illustrated London News.)

It would be interesting to know the number of tail feathers in this hybrid and whether such dominant length might have brought out a large number of feathers. A case in point is Reeve's $\times$ Common Pheasant, which has twenty tail feathers while both parents have eighteen. A white cheekpatch in this hybrid and yellow breast band exhibited by a 
cross between Golden and Lady Amherst's Pheasant are not known in there respective parents. Mr. Kinnear also exhibited a number of skins of hybrid Ducks from the British Museum collection at the same occasion.

No hybrid Eidcr-I)ucks were reported in the above publication. However I recollect examining a specimens exhibited by T. N. Krabbe at the Copenhagen Congress in 1926, including a hybrid between Somateria mollissima and S. v-nigra from Greenland, a well known occurence in that country. (Krobbe, T. N, Vl. International Ornithological Congress in Copenlagen 1926, 1 pl., pub. Feb. 19, 1929, I have not seen this publication myself).

Mr. Blaauw of Hilversum, Holland was so good as to inform me of many hybrid waterfowls bred in his park.

They are,

\begin{tabular}{|c|c|c|}
\hline o Branta minima & $x$ & \& Chen rossi \\
\hline "Chen caerulescens & $x$ & $"$ Anser erythropus \\
\hline$"$ Nettion crecca & $x$ & "Dafila acuta \\
\hline 11 & $x$ & " previous hybrid \\
\hline
\end{tabular}

(Not to be distinguished from pure $N$. crecca.)

" Nhroca africana $\times \quad$ \& Netta rufina

"Nettion flairostris $\times$ " Poecilonetta erylhrorhyncha

1 Poecilonetla erythrorhyncha $\times$ \& previous hybrid (a)

(Almost, not quite, like true erythirorhyncha.)

"Nettion flavirostris $x \quad q$ previous hybrid (a)

(Almost, not quite, like true flavirosris.)

" Anser superciliosa $\times \quad$ 옹 Domestic white call duck.

Result, small white ducks with black bill and no yellow shine in the plumage but pure white. 
Kuroda writes, (Some rare Anatidae obtained during this Shooting Season 1928-29 in Japan ante p. 117) five examples of interchange of sex among these ducks. They are, Teal, threee xamples. Mallard 1, and Pintail 1. Seven examples of Falcata-Widgeon hybrid are known to him ( $C f$. Variation, Hachisuka, p. 58, 1928). Dr. Kuroda showed me at his duck pond in autumu last year a beautiful male hybrid, a most gorgeous bird but with no developed crest and no falcated feathers showing the character of the widgeon.

This individual migrates yearly in association with widgeon which is some weeks earlier than Falcated Teal. Falcatawidgeon hybrid is better known to Dr. Kuroda than to any waterfowl specialist.

Both Dr. Blaauw and Dr. J. C. Philips write that plate 16 in my book dipidting Wyandotte $\times$ Turkey is of doubtful authenticity. The bird figured looks altogether too fowl-like. Its well developed combs and wattles do not suggest any resemblance to the turkey. It appears that the first cross sometimes, not always, has both parent's characters equally divided. An example is Japanese Pheasant and domestic fowl hybrid (plate XIV, Pheasants of Japan, Kuroda, 1926). In this case the cross always resembles the bantam with stronger flight, the face and the tail being exactly like that of the fowl.

Hybrids between Chrysolophus pictus mut. obscurus and Phasianus mut. tenebrosus were successfully reared in my pen during the last season. The males turning into full plumage from the beginning of September. The common pleasant does so in the first autumn but the Golden pheasant male remains in juvenile plumage till the second summer. They have spurs like P. mut. tenebrosus. This cross appears nearer to Phasianus than Chrysolophus. It is a first record of the above two 
species and, it is so to any mulant inter crosses.

An announcement was made of a probable crane hybrid (Variation, Hachisuka, p. 61, 1928) last year, aud an opportunity occured agrin to make a close examination of this particular specimen with a quantity of comparative materials at hand. On close examination it appears by no means a genuine species or abnormal individual but it exhibits many characters rarely found among the F. 1 of avian hybrids.

Inherited characteristics of parents appearing more dominant may be Megalornis japonensis and the other might have been suspected to be Megalornis grus litfordi.

The specimen is nearer $M$. japonensis in dimension and about 7 inches shorter in the wings, and half an inch in culmen and an inch each in tarsus and tail longer.

Megalornis japonensis

Wing $2 \mathrm{f} .9 \mathrm{in}$.

Cul. $\quad 4.8$

Tar. $\quad 10.5$

Tail $\quad 9.2$

M. q. lilfordi

IV. 1f. 10

C. $\quad 3.9$

'Tar. $\quad 9.4$

T. $\quad 9.2$

$M$. japonensis $\times M . g$. lilfordi

W. 2. 2.

C. $\quad 5.2$ Gape 5.8 inch

Tar. 11.9 Mid. toe $4.4 \mathrm{in}$. with Claw (along the upper edge)

3.8 without $\mathrm{Claw}$

Tail 10.2 (central) number 12 
It is not out of the ordinary to find a hybrid larger than both parents. The general colouration of the plumage appears rather smoky and slate blue and may recall the Megaloritis monachus. This species however is too small, the wing only measuring about 14 inches, shorter than the Japanese Crane. For this reason $M$. monachus can not be taken into consideration. The bird in question and lilfordi have the entire crown covered with bristles, the red pateh being restricted towards the lower half of the neck. This character is more pronounced in the bird under scrutiny. The Blackish colour of the nape is like lilfordi, also the fuce, the upper neck is very like, but the white of the lower neck is common with japosensis.

Primaries black as in lilfordi, tail black and slate blue towards the basal half which is like lilfordi but much darker.

Median wing covert grey, primary covert, which is pure white in japonensis, is black like lilfordi. The remaining part of the body is generally white washed with slate grey.

The scapulars are slate black with a few white feathers at the right side. The upper back dark slate, darker than lilfordi, mixed with fairly clean white feathers. At close examination one can find the dorsal part of the body not symmetrically marked. The lower back and rump pure white as in japonensis. The inner secondaries pure black, but it is slato grey in some feathers represented by small quantity or only on one side of a web. The upper mandible light in colour towards the tip and the lower is half blackish towards the base.

This lighter coloured part is now difficult to tell how it was when the bird was alive but it was presumably a greenish colour or yellowish as the case in the young bird.

Both species lilfordi and japonensis breed in east Siberia probably on much the same ground and winter in the south. 
They flock a great number but two species are kept apart in a flight. It is of interest to know with which species the hybrid has kept its company.

D. C. Worcester recorded hybrid boobies, Sula leucogastra $\times$ S. cyanops, on Usong Islaud at the northern end of Tub-bataha Reef in the Philippines (Philippine Journ. Sc. 6, 179, 1911).

He writes as: What interested me still more was to find a female Sula cyanops mated with a male Sulc leucogastra. The latter was in full breedurg plumage and his sex was conclusively proved by the color of his legs and feet and of the bare skin of his head.

The strangely matched pair had a nest to which they promptly returned whenever I drove them away. It contained no eggs, but this was a lack which was evidently soon to be remedied! There was no possible doubt that the birds were mated, and it seems not improbable that the three hybrid individuals observed, all of which proved to be fully adult, may have been their offspring. 